\title{
Ethics in the Accounting Curriculum
}

\author{
James H. Thompson \\ Central Washington University \\ 2400 S. $240^{\text {th }}$ Street, Des Moines, WA 98198, United States \\ Tel: 1-206-439-3800 x3839 E-mail: jht@cwu.edu
}

Received: Jan. 30, 2013 Accepted: March 1, 2013 Published: May 1, 2013

doi:10.5296/jse.v3i2.3184 URL: http://dx.doi.org/10.5296/jse.v3i2.3184

\begin{abstract}
The number of corporate debacles in recent history has been a great concern to the financial community. From Enron to Bear Stearns, the events have highlighted that greed, incompetence, and deception exist systemically. After these and other similar events, the importance of professional ethics intensified. Has the concern for improved ethical behavior compelled academic institutions to provide greater emphasis on ethics in accounting degree programs?

Several findings emerged in this study. First, ethics is more commonly part of the course description than it is to be part of the course title. Second, there is greater emphasis on ethics in undergraduate education than in graduate education. The findings also indicate that the extent to which ethics is included in course descriptions is extremely inconsistent and variable across academic levels and geographical regions. Finally, standalone ethics courses are less common than integration of ethics into one or more courses at both levels and for all geographic regions.
\end{abstract}

Keywords: Ethics, Accounting Curriculum 


\section{Introduction}

The number of corporate debacles in recent history has been a great concern to the financial community. From Enron to Bear Stearns, the events have highlighted that greed, incompetence, and deception exist systemically. After these and other similar events, the importance of professional ethics intensified. Has this concern compelled academic institutions to provide greater emphasis on ethics in accounting degree programs?

The purpose of this paper is to document the extent to which ethics is included in undergraduate and graduate accounting curricula of private and public colleges and universities in the United States. Such documentation is needed to assess the adequacy of ethics education among accounting students..

The paper makes three significant assumptions. First, the highest ranked private and public schools in each state are representative of other schools that offer degrees in accounting. Second, the use of the word "ethics" in the course title or in the course description from online school catalogs is evidence of a standalone ethics course or of ethics being integrated into one or more courses throughout the accounting curriculum. Courses that have "ethics" in the title are assumed to represent standalone ethics courses and are assumed to provide more extensive coverage of ethics than courses that integrate ethics into course content. Finally, the study assumes that all standalone ethics courses are comparable and courses that integrate ethics are comparable.

\section{Background}

California Senate Bill No. 773 (SB 773) was chaptered by the state of California in September 26, 2011. This bill was written to amend the current educational requirements for those pursuing an accounting license. SB 773 states that after January 1, 2014 applicants will be required to complete an "additional 10 units of ethics study." The bill stipulates that an advisory committee be established to recommend to the board (California Board of Accountancy) ethics study guidelines to be adopted. This committee will be authorized to determine "that a course or portion of a course satisfies the ethics study requirements." (State of California Bill information) Currently, each school may determine the method and amount of accounting ethics in education unless the state accountancy boards mandate a specific requirement.

Miller and Becker (2011) of the University of Wisconsin, Eau Claire studied how ethics is integrated into accounting curricula. Their research examined the level of ethics integration across accounting curricula, provided an update on the level of coverage that exists today, and identified the specific ethics topics being covered. Their study was conducted through electronic surveys of 1,200 accounting faculty members across the nation over a six-week time period, with a reminder sent out at the half-way point. They surveyed 235 faculty members from across the United States. The results of the survey indicated that the overall attitude toward teaching ethics was positive, with 78 percent support teaching ethics, 87 percent are committed to integrating ethics across curriculum, and 78 percent felt that school administration supports the concept. The results also showed that only 25 percent of the 
schools had separate accounting ethics courses, and 13.85 percent have these classes as requirements for all accounting majors.

Thompson, McCoy, and Wallestad (1992) also studied the way in which ethics is incorporated into the accounting curriculum. Their study surveyed accounting program administrators. Two approaches to teaching ethics were identified: the discrete approach, which utilizes separate ethics courses, and the pervasive approach, which incorporates ethics into existing accounting courses. Their study found that most programs employed the pervasive approach. They reported that only 18 percent of undergraduate programs and 8 percent of master's programs required a separate ethics course, but 97 percent of all accounting programs incorporated ethics into one o or more accounting or business courses.

\section{Methodology}

This study considers the frequency of separate ethics courses and of the integration of ethics into other accounting courses at 100 universities in the United States. Universities were selected from the UsUniversities.ca website. The website ranks public and private universities based on SAT percentiles. UsUniversities.ca derives its data from National Center for Education Statistics and common data sets released by colleges. Only public and private schools that offer degrees in accounting were selected for this study. The highest ranked public and private universities from each state were selected. Our methodology did not identify any university (public or private) for Wyoming, a public university for Washington D.C., or a private university for Arizona, Montana, New Mexico, or Nevada. Thus, the total number of universities totaled 95. Website addresses for each university were obtained from the Accounting Faculty Directory (2011). Appendix 1 lists the universities that were selected.

The data in the study were taken from each university's website. Specific data that were gathered included whether the university had standalone ethics courses and, if so, whether the course was taught at the undergraduate or graduate level. Also, accounting course descriptions were searched for the use of the word "ethics" and its derivatives as a basis for determining whether ethics was integrated into other accounting course work.

\section{Data Analysis}

Data was gathered on a spreadsheet. A summary of the data is contained in Appendix 2. In situations where selected data were not available, the notation "N/A" appears. Data was not available 9.3 percent of the time. For schools that did not offer a program (either undergraduate or graduate), the notation " $\mathrm{X}$ " appears.

Mississippi was the only state in which universities included ethics both in the course title and within course descriptions both for public and private universities and at both the undergraduate and graduate levels. Conversely, none of the Massachusetts, Oregon, and Texas universities included ethics in the course title or as part of the description at either academic level.

Eight universities included ethics in the course title and within course description for both 


\section{Macrothink}

undergraduate and graduate levels. These universities were University of Illinois at Springfield, University of Notre Dame, Saint Joseph's College, Concordia University (St. Paul), Mississippi University for Women, Belhaven College, Elon University, and University of Vermont.

Alternatively, 12 universities did not have ethics in the course title or in any course descriptions for either academic level. These universities were: Worcester State College, Harvard University, University of Minnesota (Minneapolis), Southern New Hampshire University, SUNY College at New Paltz, the Ohio State University, University of Tulsa, University of Oregon, University of Portland, The University of Texas at Dallas, Brigham Young University, and University of Washington.

Because the number of undergraduate programs is not equal to the number of graduate programs analyzed, all results that compared these groups were based on percentages. Approximately 28 percent of the universities studied offered only one academic level, 79 percent which offered only an undergraduate accounting degree program.

Overall, "ethics" was included in the course title 25 percent of the time and within the course description 74 percent of the time. These percentages are consistent with the Miller and Becker (2011) findings. Based on these findings, a standalone ethics course is not common.

When comparing undergraduate and graduate offerings, "ethics" is included in either the course title or course description 72 percent of the time for undergraduate programs and 53 percent of the time for graduate programs.

"Ethics" appears in the course title 24 percent of the time in undergraduate course work and 26 percent of the time in graduate course work. On the other hand, "ethics" is contained in course descriptions of undergraduate and graduate programs 81 and 63 percent of the time, respectively. Figures 1 and 2 show these results.

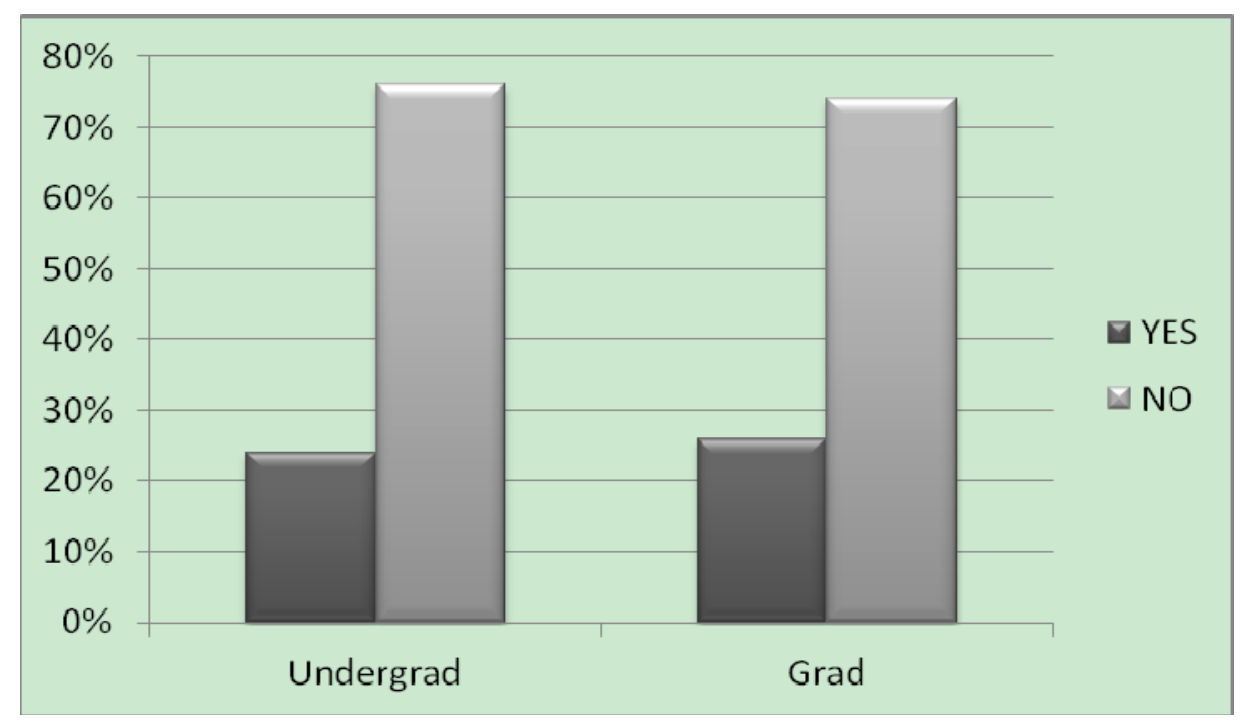

Figure 1. Percentage of Times "Ethics" in the Course Title 


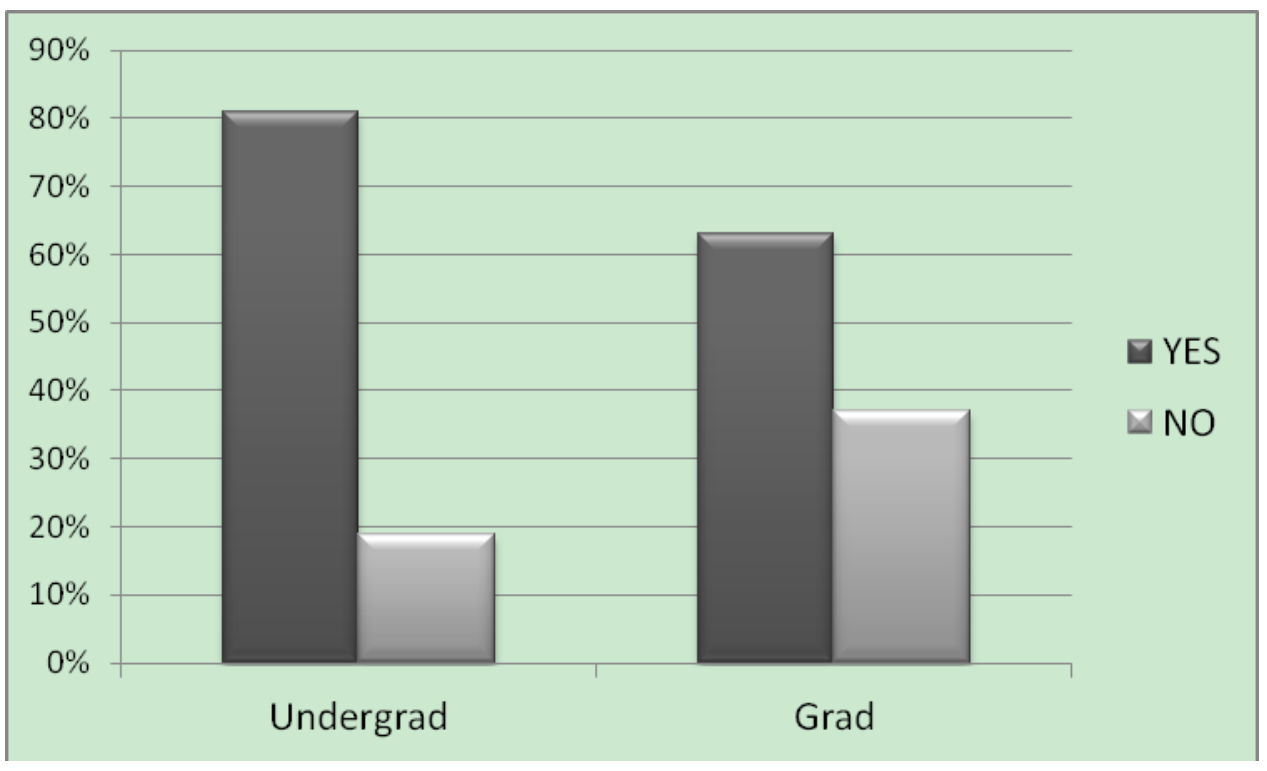

Figure 2. Percentage of Times "Ethics" in the Course Description

When the data are viewed by geographic region, "ethics” is included as part of the course title between 19-29 percent of the time, with the West showing the lowest percentage and the Northeast showing the highest percentage. On the other hand, "ethics" was included in course description between 40-89 percent of the time, with the Southwest showing the lowest percentage and the Southeast showing the highest percentage. However, the variance in the use of "ethics" in the course description was much wider than for the use of "ethics" in the course title. Figure 3 shows these results.

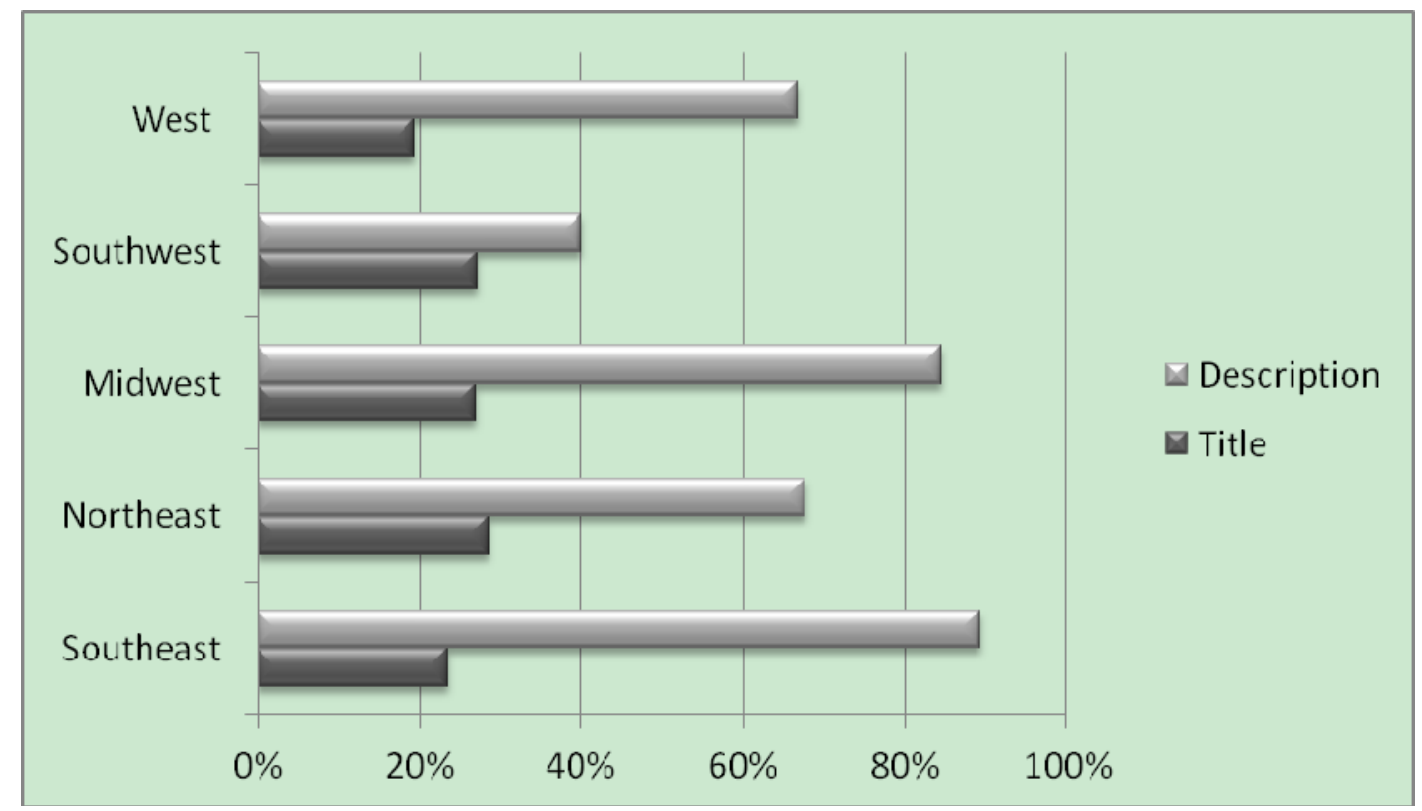

Figure 3. Percentage of Times “Ethics” is Included in Course Title or Description by Region 


\section{Conclusion}

Several findings emerged in this study. First, "ethics" is more commonly part of the course description than a part of the course title. Secondly, there is greater emphasis on ethics in undergraduate education than in graduate education. When examining whether "ethics" is used as part of the title versus part of the description, undergraduate accounting courses include the word "ethics" much more frequently in course descriptions. There is very little difference in the amount of standalone ethics courses offered between the academic levels. There is some variance in the use of "ethics" in the course title when comparing across regions, but a wider variance exists in the use of "ethics" when comparing the course descriptions. These findings indicate that the extent to which ethics is included in course descriptions is inconsistent and varies considerably across academic levels and regions.

Considering the numerous ethical scandals that have occurred in the business world, ethics should have a greater and more consistent emphasis in accounting education. It is concerning that ethics is infrequently a standalone course and often not part of the curriculum at all-especially at the graduate level. More states should take an initiative like California did with the passage of SB 773, which require additional course work in ethics.

Three recommendations are made by this study. First, standalone ethics courses should be promoted rather than simply incorporating ethics into existing courses. This action will encourage greater focus on the importance of ethics in a business environment. Second, ethics courses should be equally accessible to both undergraduate and graduate accounting programs. Finally, state accountancy boards and other professional bodies should promote greater awareness of the need to emphasize ethics in education by mandating requirements.

\section{References}

Hasselback, J. (2011). Accounting faculty directory. New Jersey: Prentice Hall.

Miller, W. F., \& Becker, D. A. (October 2011) Ethics in the accounting curriculum: what is really being covered? The Clute Institute American Journal of Business Education. Retrieved from http://journals.cluteonline.com/index.php/AJBE/article/view/6057/6135

State of California Bill Information. Retrieved from http://www.leginfo.ca.gov/pub/11-12/bill/sen/sb_0751-0800/sb_773_bill_20110926_chaptere d.pdf

Thompson, J.H., T. McCoy, \& Wallestad, D.A. (1992). The Incorporation of Ethcis into the Accounting Curriculum. Advances in Accounting., 10, 91-103.

Top US Universities. Retrieved from http://www.UsUniversities.ca

\section{Appendix}

Appendix 1: School websites:

Tuskegee University: www.tuskegee.edu

Alabama State University: www.alasu.edu

Alaska Pacific University: www.alaskapacific.edu 


\section{Macrothink}

University of Alaska, Anchorage: www.uaa.alaska.edu

Arizona State University: www.asu.edu

Lyon College: www.lyon.edu

University of Arkansas at Pine Bluff: www.uapb.edu

University of Southern California: www.usc.edu

University of California - Berkeley: www.berkeley.edu

University of Denver: www.du.edu

University of Colorado - Colorado Springs: www.uccs.edu

Quinnipiac University: www.quinnipiac.edu

University of Connecticut: www.uconn.edu

Wesley College: www.wesley.edu

Delaware State University: www.desu.edu

Georgetown University: www.georgetown.edu

University of Miami: www.miami.edu

University of Florida: www.ufl.edu

Brenau University: www.brenau.edu

Savannah State University: www.savannahstate.edu

Brigham Young University - Hawaii: www.byuh.edu

University of Hawaii at Hilo: www.hilo.hawaii.edu

Brigham Young University - Idaho: www.byui.edu

University of Idaho: www.uidaho.edu

Roosevelt University: www.roosevelt.edu

University of Illinois at Springfield: www.uis.edu

University of Notre Dame: www.nd.edu

Indiana University - Bloomington: www.iub.edu

Graceland University - Lamoni: www.graceland.edu

University of Northern Iowa: www.uni.edu

Benedictine College: www.benedictine.edu

Wichita State University: www.wichita.edu 


\section{Macrothink}

Spalding University: www.spalding.edu

Kentucky State University: www.kysu.edu

Louisiana State University: www.lsu.edu/

Tulane University: tulane.edu/

University of Maine: www.umaine.edu/

Saint Joseph’s College: www.sjcme.edu/

University of Baltimore: www.ubalt.edu/index.cfm

Loyola College: www.loyola.edu/

Worcester State College: www.worcester.edu/default.aspx

Harvard University: www.harvard.edu/

University of Michigan - Ann Arbor: www.umich.edu/

Andrews University: www.andrews.edu/

University of Minnesota - Minneapolis: www1.umn.edu/twincities/index.html

Concordia University - St. Paul: www.csp.edu/

Mississippi University for Women: web2.muw.edu/index.php

Belhaven College: www.belhaven.edu/

University of Missouri - Kansas City: www.umkc.edu/

Washington University: wustl.edu/

Montana State University: www.montana.edu/

University of Nebraska - Kearny: www.unk.edu/

Doane College: www.doane.edu/

University of Nevada - Las Vegas: go.unlv.edu/

University of New Hampshire - Durham: www.unh.edu/

Southern New Hampshire University: www.snhu.edu/

The College of New Jersey: www.tcnj.edu/

Farleigh Dickinson University - Teaneck NJ: www.fdu.edu/

New Mexico State University - Las Cruces: www.nmsu.edu/

SUNY College at New Paltz: www.newpaltz.edu/

Marist College: www.marist.edu/ 
Appalachian State University: www.appstate.edu/

Elon University: www.elon.edu/home/

Minot State University: www.minotstateu.edu/

Jamestown College: www.jc.edu/

Ohio State University: www.osu.edu/

Case Western Reserve University: www.case.edu/

University of Oklahoma: www.ou.edu/web.html

University of Tulsa: www.utulsa.edu/

University of Oregon: www.uoregon.edu/

University of Portland: www.up.edu/

University of Pittsburgh: www.pitt.edu/

University of Pennsylvania: www.upenn.edu/

University of Rhode Island: www.uri.edu/

Providence College: www.providence.edu/Pages/default.aspx

College of Charleston: www.cofc.edu/

Furman University: www2.furman.edu/Pages/default.aspx

Northern State University: www.northern.edu/Pages/index.aspx

Augustana College SD: www.augie.edu/

The University of Tennessee- Knoxville: www.utk.edu/

Vanderbilt University: www.vanderbilt.edu/

The University of Texas at Dallas: www.utdallas.edu/

Rice University: www.rice.edu/

University of Utah: www.utah.edu/

Brigham Young University - Utah: home.byu.edu/home/

University of Vermont: www.uvm.edu/

Saint Michaels College: www.smcvt.edu/

Collage of William and Mary: www.wm.edu/

Washington and Lee University: www.wlu.edu/x6.xml

University of Washington: www.washington.edu/ 
Gonzaga University: www.gonzaga.edu/

Georgetown University: www.georgetown.edu/

Shepherd University: www.shepherd.edu/

Alderson Broaddus College: www.ab.edu/

University of Wisconsin - Madison: www.wisc.edu/

Marquette University: www.marquette.edu/

Appendix 2: Data Collected by State and University

\begin{tabular}{|c|c|c|c|c|c|}
\hline State & School & Public/Private & Undergrad/Grad & $\begin{array}{l}\text { Ethics in } \\
\text { Course } \\
\text { Title }\end{array}$ & $\begin{array}{l}\text { Ethics in } \\
\text { Description }\end{array}$ \\
\hline \multirow[t]{4}{*}{ Alabama } & $\begin{array}{ll}\text { Alabama } & \text { State } \\
\text { University } & \end{array}$ & Public & Undergrad & No & N/A \\
\hline & & & Grad & No & N/A \\
\hline & Tuskegee University & Private & Undergrad & Yes & Yes \\
\hline & & & Grad & $\mathrm{X}$ & $\mathrm{X}$ \\
\hline \multirow[t]{4}{*}{ Alaska } & $\begin{array}{l}\text { University of Alaska, } \\
\text { Anchorage }\end{array}$ & Public & Undergrad & No & N/A \\
\hline & & & Grad & $\mathrm{X}$ & $\mathrm{X}$ \\
\hline & $\begin{array}{ll}\text { Alaska } & \text { Pacific } \\
\text { University } & \end{array}$ & Private & Undergrad & Yes & Yes \\
\hline & & & Grad & $\mathrm{X}$ & $\mathrm{X}$ \\
\hline \multirow[t]{4}{*}{ Arizona } & $\begin{array}{ll}\text { Arizona } & \text { State } \\
\text { University } & \\
\end{array}$ & Public & Undergrad & Yes & Yes \\
\hline & & & Grad & No & N/A \\
\hline & None & Private & Undergrad & $\mathrm{X}$ & $\mathrm{X}$ \\
\hline & & & Grad & $\mathrm{X}$ & $\mathrm{X}$ \\
\hline \multirow[t]{4}{*}{ Arkansas } & $\begin{array}{l}\text { University of Arkansas } \\
\text { at Pine Bluff }\end{array}$ & Public & Undergrad & No & Yes \\
\hline & & & Grad & $\mathrm{X}$ & $\mathrm{X}$ \\
\hline & Lyon College & Private & Undergrad & No & Yes \\
\hline & & & Grad & $\mathrm{X}$ & $\mathrm{X}$ \\
\hline \multirow[t]{4}{*}{ California } & $\begin{array}{l}\text { University of California } \\
\text { - Berkley }\end{array}$ & Public & Undergrad & Yes & Yes \\
\hline & & & Grad & No & N/A \\
\hline & $\begin{array}{l}\text { University of Southern } \\
\text { California }\end{array}$ & Private & Undergrad & No & N/A \\
\hline & & & Grad & No & Yes \\
\hline Colorado & $\begin{array}{l}\text { University of Colorado - } \\
\text { Colorado Springs }\end{array}$ & Public & Undergrad & No & N/A \\
\hline
\end{tabular}




\begin{tabular}{|c|c|c|c|c|c|}
\hline & & & Grad & No & $\mathrm{N} / \mathrm{A}$ \\
\hline & University of Denver & Private & Undergrad & No & $\mathrm{N} / \mathrm{A}$ \\
\hline & & & Grad & Yes & Yes \\
\hline \multirow[t]{4}{*}{ Connecticut } & $\begin{array}{l}\text { University of } \\
\text { Connecticut }\end{array}$ & Public & Undergrad & No & Yes \\
\hline & & & Grad & Yes & Yes \\
\hline & Quinnipiac University & Private & Undergrad & No & Yes \\
\hline & & & Grad & $\mathrm{X}$ & $X$ \\
\hline \multirow[t]{4}{*}{ Delaware } & $\begin{array}{ll}\text { Delaware } & \text { State } \\
\text { University } & \\
\end{array}$ & Public & Undergrad & No & Yes \\
\hline & & & Grad & $\mathrm{X}$ & $\mathrm{X}$ \\
\hline & Wesley College & Private & Undergrad & Yes & Yes \\
\hline & & & Grad & $\mathrm{X}$ & $\mathrm{X}$ \\
\hline \multirow[t]{4}{*}{ Florida } & University of Florida & Public & Undergrad & No & Yes \\
\hline & & & Grad & No & Yes \\
\hline & University of Miami & Private & Undergrad & No & N/A \\
\hline & & & Grad & No & N/A \\
\hline \multirow[t]{4}{*}{ Georgia } & $\begin{array}{ll}\text { Savannah } & \text { State } \\
\text { University } & \\
\end{array}$ & Public & Undergrad & No & Yes \\
\hline & & & Grad & $\mathrm{X}$ & $\mathrm{X}$ \\
\hline & Brenau University & Private & Undergrad & No & N/A \\
\hline & & & Grad & No & N/A \\
\hline \multirow[t]{4}{*}{ Hawaii } & $\begin{array}{l}\text { University of Hawaii at } \\
\text { Hilo }\end{array}$ & Public & Undergrad & No & Yes \\
\hline & & & Grad & $\mathrm{X}$ & $X$ \\
\hline & $\begin{array}{l}\text { Brigham Young } \\
\text { University - Hawaii }\end{array}$ & Private & Undergrad & Yes & Yes \\
\hline & & & Grad & $X$ & $\mathrm{X}$ \\
\hline \multirow[t]{4}{*}{ Idaho } & University of Idaho & Public & Undergrad & No & N/A \\
\hline & & & Grad & No & Yes \\
\hline & $\begin{array}{l}\text { Brigham Young } \\
\text { University - Idaho }\end{array}$ & Private & Undergrad & No & Yes \\
\hline & & & Grad & $X$ & $X$ \\
\hline \multirow[t]{4}{*}{ Illinois } & $\begin{array}{l}\text { University of Illinois at } \\
\text { Springfield }\end{array}$ & Public & Undergrad & Yes & Yes \\
\hline & & & Grad & Yes & Yes \\
\hline & Roosevelt University & Private & Undergrad & No & Yes \\
\hline & & & Grad & No & Yes \\
\hline \multirow[t]{3}{*}{ Indiana } & $\begin{array}{l}\text { Indiana University - } \\
\text { Bloomington }\end{array}$ & Public & Undergrad & No & Yes \\
\hline & & & Grad & No & N/A \\
\hline & University of Notre & Private & Undergrad & Yes & Yes \\
\hline
\end{tabular}




\begin{tabular}{|c|c|c|c|c|c|}
\hline & Dame & & & & \\
\hline & & & Grad & Yes & Yes \\
\hline \multirow[t]{4}{*}{ Iowa } & $\begin{array}{l}\text { University of Northern } \\
\text { Iowa }\end{array}$ & Public & Undergrad & No & N/A \\
\hline & & & Grad & No & $\mathrm{N} / \mathrm{A}$ \\
\hline & $\begin{array}{l}\text { Graceland University - } \\
\text { Lamoni }\end{array}$ & Private & Undergrad & No & N/A \\
\hline & & & Grad & $X$ & $X$ \\
\hline \multirow[t]{4}{*}{ Kansas } & Wichita State University & Public & Undergrad & No & Yes \\
\hline & & & Grad & No & Yes \\
\hline & Benedictine College & Private & Undergrad & No & Yes \\
\hline & & & Grad & $X$ & $X$ \\
\hline \multirow[t]{4}{*}{ Kentucky } & $\begin{array}{ll}\text { Kentucky } & \text { State } \\
\text { University } & \\
\end{array}$ & Public & Undergrad & No & Yes \\
\hline & & & Grad & $X$ & $\mathrm{X}$ \\
\hline & Spalding University & Private & Undergrad & No & Yes \\
\hline & & & Grad & $\mathrm{X}$ & $\mathrm{X}$ \\
\hline \multirow[t]{4}{*}{ Louisiana } & $\begin{array}{ll}\text { Louisiana } & \text { State } \\
\text { University } & \\
\end{array}$ & Public & Undergrad & No & Yes \\
\hline & & & Grad & Yes & Yes \\
\hline & Tulane University & Private & Undergrad & $X$ & $\mathrm{X}$ \\
\hline & & & Grad & No & Yes \\
\hline \multirow[t]{4}{*}{ Maine } & University of Maine & Public & Undergrad & No & Yes \\
\hline & & & Grad & $\mathrm{X}$ & $\mathrm{X}$ \\
\hline & Saint Joseph's College & Private & Undergrad & Yes & Yes \\
\hline & & & Grad & $\mathrm{X}$ & $\mathrm{X}$ \\
\hline \multirow[t]{4}{*}{ Maryland } & University of Baltimore & Public & Undergrad & No & Yes \\
\hline & & & Grad & $X$ & $\mathrm{X}$ \\
\hline & Loyola College & Private & Undergrad & No & Yes \\
\hline & & & Grad & $\mathrm{X}$ & $\mathrm{X}$ \\
\hline \multirow[t]{4}{*}{ Massachusetts } & Worcester State College & Public & Undergrad & No & No \\
\hline & & & Grad & $\mathrm{X}$ & $\mathrm{X}$ \\
\hline & Harvard University & Private & Undergrad & $X$ & $\mathrm{X}$ \\
\hline & & & Grad & No & No \\
\hline \multirow[t]{4}{*}{ Michigan } & $\begin{array}{l}\text { University of Michigan } \\
\text {-Ann Arbor }\end{array}$ & Public & Undergrad & $\mathrm{X}$ & $X$ \\
\hline & & & Grad & No & Yes \\
\hline & Andrews University & Private & Undergrad & No & Yes \\
\hline & & & Grad & $X$ & $X$ \\
\hline \multirow[t]{2}{*}{ Minnesota } & $\begin{array}{l}\text { University of Minnesota } \\
\text {-Minneapolis }\end{array}$ & Public & Undergrad & No & No \\
\hline & & & Grad & No & No \\
\hline
\end{tabular}




\begin{tabular}{|c|c|c|c|c|c|}
\hline & $\begin{array}{l}\text { Concordia University - } \\
\text { St. Paul }\end{array}$ & Private & Undergrad & Yes & Yes \\
\hline & & & Grad & $\mathrm{X}$ & $\mathrm{X}$ \\
\hline \multirow[t]{4}{*}{ Mississippi } & $\begin{array}{l}\text { Mississippi University } \\
\text { for Women }\end{array}$ & Public & Undergrad & Yes & Yes \\
\hline & & & Grad & $\mathrm{X}$ & $\mathrm{X}$ \\
\hline & Belhaven College & Private & Undergrad & Yes & Yes \\
\hline & & & Grad & $\mathrm{X}$ & $\mathrm{X}$ \\
\hline \multirow[t]{4}{*}{ Missouri } & $\begin{array}{l}\text { University of Missouri } \\
\text {-Kansas City }\end{array}$ & Public & Undergrad & Yes & Yes \\
\hline & & & Grad & No & Yes \\
\hline & Washington University & Private & Undergrad & Yes & Yes \\
\hline & & & Grad & No & No \\
\hline \multirow[t]{4}{*}{ Montana } & $\begin{array}{ll}\text { Montana } & \text { State } \\
\text { University } & \end{array}$ & Public & Undergrad & No & Yes \\
\hline & & & Grad & Yes & Yes \\
\hline & None & Private & Undergrad & $\mathrm{X}$ & $\mathrm{X}$ \\
\hline & & & Grad & $\mathrm{X}$ & $\mathrm{X}$ \\
\hline \multirow[t]{4}{*}{ Nebraska } & $\begin{array}{l}\text { University of Nebraska } \\
\text {-Kearny }\end{array}$ & Public & Undergrad & Yes & N/A \\
\hline & & & Grad & $\mathrm{X}$ & $\mathrm{X}$ \\
\hline & Doane College & Private & Undergrad & No & Yes \\
\hline & & & Grad & $\mathrm{X}$ & $\mathrm{X}$ \\
\hline \multirow[t]{4}{*}{ Nevada } & $\begin{array}{l}\text { University of Nevada - } \\
\text { Las Vegas }\end{array}$ & Public & Undergrad & No & Yes \\
\hline & & & Grad & No & Yes \\
\hline & None & Private & Undergrad & $\mathrm{X}$ & $\mathrm{X}$ \\
\hline & & & Grad & $\mathrm{X}$ & $\mathrm{X}$ \\
\hline \multirow[t]{4}{*}{ New Hampshire } & $\begin{array}{l}\text { University of New } \\
\text { Hampshire - Durham }\end{array}$ & Public & Undergrad & No & Yes \\
\hline & & & Grad & Yes & Yes \\
\hline & $\begin{array}{l}\text { Southern New } \\
\text { Hampshire University }\end{array}$ & Private & Undergrad & No & No \\
\hline & & & Grad & No & No \\
\hline \multirow[t]{4}{*}{ New Jersey } & $\begin{array}{l}\text { The College of New } \\
\text { Jersey }\end{array}$ & Public & Undergrad & No & Yes \\
\hline & & & Grad & $\mathrm{X}$ & $\mathrm{X}$ \\
\hline & $\begin{array}{lr}\text { Farleigh Dickinson } \\
\text { University - Teaneck NJ }\end{array}$ & Private & Undergrad & Yes & Yes \\
\hline & & & Grad & No & No \\
\hline New Mexico & $\begin{array}{l}\text { New Mexico State } \\
\text { University - Las Cruces }\end{array}$ & Public & Undergrad & No & No \\
\hline
\end{tabular}




\begin{tabular}{|c|c|c|c|c|c|}
\hline & & & Grad & Yes & Yes \\
\hline & None & Private & Undergrad & $\mathrm{X}$ & $\mathrm{X}$ \\
\hline & & & Grad & $\mathrm{X}$ & $\mathrm{X}$ \\
\hline \multirow[t]{4}{*}{ New York } & $\begin{array}{l}\text { SUNY College at New } \\
\text { Paltz }\end{array}$ & Public & Undergrad & No & No \\
\hline & & & Grad & No & No \\
\hline & Marist College & Private & Undergrad & No & Yes \\
\hline & & & Grad & $\mathrm{X}$ & $\mathrm{X}$ \\
\hline \multirow[t]{4}{*}{ North Carolina } & $\begin{array}{ll}\text { Appalachian } & \text { State } \\
\text { University } & \end{array}$ & Public & Undergrad & No & Yes \\
\hline & & & Grad & No & Yes \\
\hline & Elon University & Private & Undergrad & Yes & Yes \\
\hline & & & Grad & $\mathrm{X}$ & $\mathrm{X}$ \\
\hline \multirow[t]{4}{*}{ North Dakota } & Minot State University & Public & Undergrad & No & Yes \\
\hline & & & Grad & $\mathrm{X}$ & $\mathrm{X}$ \\
\hline & Jamestown College & Private & Undergrad & No & Yes \\
\hline & & & Grad & $\mathrm{X}$ & $\mathrm{X}$ \\
\hline \multirow[t]{4}{*}{ Ohio } & Ohio State University & Public & Undergrad & No & No \\
\hline & & & Grad & No & No \\
\hline & $\begin{array}{l}\text { Case Western Reserve } \\
\text { University }\end{array}$ & Private & Undergrad & No & Yes \\
\hline & & & Grad & No & Yes \\
\hline \multirow[t]{4}{*}{ Oklahoma } & University of Oklahoma & Public & Undergrad & Yes & Yes \\
\hline & & & Grad & No & Yes \\
\hline & University of Tulsa & Private & Undergrad & No & No \\
\hline & & & Grad & No & No \\
\hline \multirow[t]{4}{*}{ Oregon } & University of Oregon & Public & Undergrad & No & No \\
\hline & & & Grad & No & No \\
\hline & University of Portland & Private & Undergrad & No & No \\
\hline & & & Grad & No & No \\
\hline \multirow[t]{4}{*}{ Pennsylvania } & University of Pittsburgh & Public & Undergrad & No & No \\
\hline & & & Grad & Yes & Yes \\
\hline & \begin{tabular}{|lc} 
University & of \\
Pennsylvania & \\
\end{tabular} & Private & Undergrad & No & Yes \\
\hline & & & Grad & No & No \\
\hline \multirow[t]{4}{*}{ Rhode Island } & $\begin{array}{l}\text { University of Rhode } \\
\text { Island }\end{array}$ & Public & Undergrad & Yes & Yes \\
\hline & & & Grad & No & No \\
\hline & Providence College & Private & Undergrad & No & Yes \\
\hline & & & Grad & Yes & Yes \\
\hline \multirow[t]{2}{*}{ South Carolina } & College of Charleston & Public & Undergrad & No & Yes \\
\hline & & & Grad & No & Yes \\
\hline
\end{tabular}




\begin{tabular}{|c|c|c|c|c|c|}
\hline & Furman University & Private & Undergrad & No & Yes \\
\hline & & & Grad & $\mathrm{X}$ & $\mathrm{X}$ \\
\hline \multirow[t]{4}{*}{ South Dakota } & $\begin{array}{ll}\text { Northern } & \text { State } \\
\text { University } & \end{array}$ & Public & Undergrad & No & Yes \\
\hline & & & Grad & $\mathrm{X}$ & $X$ \\
\hline & Augustana College SD & Private & Undergrad & Yes & Yes \\
\hline & & & Grad & $X$ & $\mathrm{X}$ \\
\hline \multirow[t]{4}{*}{ Tennessee } & $\begin{array}{l}\text { The University of } \\
\text { Tennessee- Knoxville }\end{array}$ & Public & Undergrad & No & Yes \\
\hline & & & Grad & No & No \\
\hline & Vanderbilt University & Private & Undergrad & $X$ & $\mathrm{X}$ \\
\hline & & & Grad & Yes & Yes \\
\hline \multirow[t]{4}{*}{ Texas } & $\begin{array}{l}\text { The University of Texas } \\
\text { at Dallas }\end{array}$ & Public & Undergrad & No & No \\
\hline & & & Grad & No & No \\
\hline & Rice University & Private & Undergrad & $X$ & $X$ \\
\hline & & & Grad & No & No \\
\hline \multirow[t]{4}{*}{ Utah } & University of Utah & Public & Undergrad & No & Yes \\
\hline & & & Grad & No & Yes \\
\hline & $\begin{array}{l}\text { Brigham Young } \\
\text { University - Utah }\end{array}$ & Private & Undergrad & No & No \\
\hline & & & Grad & No & No \\
\hline \multirow[t]{4}{*}{ Vermont } & University of Vermont & Public & Undergrad & Yes & Yes \\
\hline & & & Grad & Yes & Yes \\
\hline & Saint Michaels College & Private & Undergrad & No & Yes \\
\hline & & & Grad & $X$ & $\mathrm{X}$ \\
\hline \multirow[t]{4}{*}{ Virginia } & $\begin{array}{l}\text { Collage of William and } \\
\text { Mary }\end{array}$ & Public & Undergrad & No & Yes \\
\hline & & & Grad & No & Yes \\
\hline & $\begin{array}{l}\text { Washington and Lee } \\
\text { University }\end{array}$ & Private & Undergrad & No & No \\
\hline & & & Grad & $X$ & $X$ \\
\hline \multirow[t]{4}{*}{ Washington } & $\begin{array}{ll}\text { University } & \text { of } \\
\text { Washington }\end{array}$ & Public & Undergrad & No & No \\
\hline & & & Grad & No & No \\
\hline & Gonzaga University & Private & Undergrad & No & Yes \\
\hline & & & Grad & Yes & Yes \\
\hline \multirow[t]{4}{*}{$\begin{array}{l}\text { Washington } \\
\text { D.C. }\end{array}$} & None & Public & Undergrad & $X$ & $X$ \\
\hline & & & Grad & $\mathrm{X}$ & $\mathrm{X}$ \\
\hline & Georgetown University & Private & Undergrad & No & Yes \\
\hline & & & Grad & No & No \\
\hline
\end{tabular}




\begin{tabular}{|l|l|l|l|l|l|}
\hline West Virginia & Shepherd University & Public & Undergrad & No & No \\
\hline & & & Grad & Yes & Yes \\
\hline & $\begin{array}{l}\text { Alderson Broaddus } \\
\text { College }\end{array}$ & Private & Undergrad & Yes & Yes \\
\hline & & & Grad & X & X \\
\hline Wisconsin & $\begin{array}{l}\text { University } \\
\text { Wisconsin- Madison }\end{array}$ & Public & Undergrad & No & Yes \\
\hline & & & Grad & No & Yes \\
\hline & Marquette University & Private & Undergrad & No & Yes \\
\hline & & & Grad & Yes & Yes \\
\hline Wyoming & None & Public & Undergrad & X & X \\
\hline & & & Grad & X & X \\
\hline & None & Private & Undergrad & X & X \\
\hline & & & Grad & $X$ & $X$ \\
\hline
\end{tabular}

\section{Copyright Disclaimer}

Copyright reserved by the author(s).

This article is an open-access article distributed under the terms and conditions of the Creative Commons Attribution license (http://creativecommons.org/licenses/by/3.0/). 